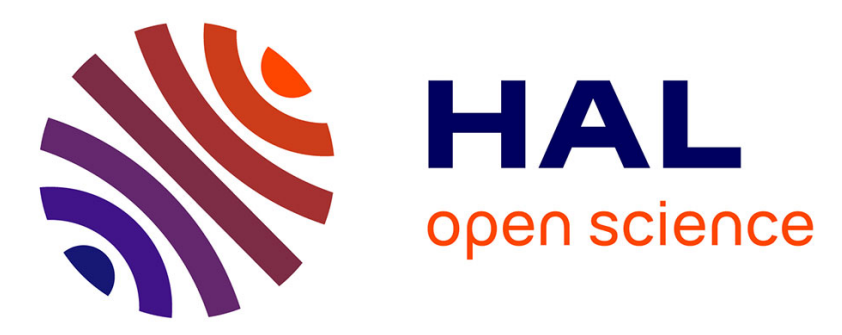

\title{
Generation of soluble oligomeric $\beta$-amyloid species via copper catalyzed oxidation with implications for Alzheimer's disease: A DFT study
}

Fredrik Haeffner, Kevin J. Barnham, Ashley I. Bush, Tore Brinck

\section{- To cite this version:}

Fredrik Haeffner, Kevin J. Barnham, Ashley I. Bush, Tore Brinck. Generation of soluble oligomeric $\beta$-amyloid species via copper catalyzed oxidation with implications for Alzheimer's disease: A DFT study. Journal of Molecular Modeling, 2009, 16 (6), pp.1103-1108. 10.1007/s00894-009-0619-6 . hal00568335

\section{HAL Id: hal-00568335 \\ https://hal.science/hal-00568335}

Submitted on 23 Feb 2011

HAL is a multi-disciplinary open access archive for the deposit and dissemination of scientific research documents, whether they are published or not. The documents may come from teaching and research institutions in France or abroad, or from public or private research centers.
L'archive ouverte pluridisciplinaire $\mathbf{H A L}$, est destinée au dépôt et à la diffusion de documents scientifiques de niveau recherche, publiés ou non, émanant des établissements d'enseignement et de recherche français ou étrangers, des laboratoires publics ou privés. 


\section{Editorial Manager(tm) for Journal of Molecular Modeling Manuscript Draft}

Manuscript Number: JMM0963R1

Title: Generation of soluble oligomeric $\beta$-amyloid species via copper catalyzed oxidation with implications for Alzheimer's disease: A DFT study

Article Type: Original paper

Keywords: Alzheimer's disease; $\beta$-amyloid; copper ion; Met35; oxidation; molecular modeling

Corresponding Author: Prof. Tore Brinck, Ph.D.

Corresponding Author's Institution: Royal Institute of Technology (KTH)

First Author: Fredrik Haeffner, PhD

Order of Authors: Fredrik Haeffner, PhD; Kevin J Barnham, PhD; Ashley I Bush, PhD; Tore Brinck, Ph.D.

Abstract: A mechanism for the oxidation of a dimeric $\beta$-amyloid copper ion complex is proposed based on DFT calculations. It involves the Met35 residue, which is believed to be important in the neurotoxicity causing Alzheimer's disease. Oxidation of Met35 is found to proceed readily with dioxygen when two Met35 residues are close to each other and the copper ion. This indicates that oxidants, such as hydrogen peroxide, are not necessary for oxidation of $\beta$-amyloid copper ion complexes. Understanding these processes could be pivotal in gaining more knowledge of this complex disease and for the development of therapeutic treatments.

Response to Reviewers: We are happy with the favorable comments by the reviewer. A short summary has been added to the manuscript as suggested by the reviewer. 


\title{
Generation of soluble oligomeric $\beta$-amyloid species via copper catalyzed oxidation with implications for Alzheimer's disease: A DFT study
}

Received: 12.08.2009 / Accepted: 28.09.2009

Fredrik Haeffner ${ }^{1,2}$, Kevin J Barnham ${ }^{3}$, Ashley I Bush ${ }^{4}$ and Tore Brinck ${ }^{1, 凶}$

${ }^{1}$ Physical Chemistry, Royal Institute of Technology S 10044 Stockholm, Sweden

${ }^{2}$ Current address: Chemical Science and Technology Laboratory, National Institute of Standards and Technology, 100 Bureau Drive, Stop 8300, Gaithersburg, MD 20899-8300

${ }^{3}$ Department of Pathology, The University of Melbourne, and The Mental Health Research Institute of Victoria, Victoria, 3010, Australia

${ }^{4}$ Laboratory for Oxidation Biology, Genetics and Aging Research Unit and Department of Psychiatry, Harvard Medical School, Massachusetts

${ }^{\circledR}$ Tel: +4687908210; Fax: +4687908210; E-mail: tore@ physchem.kth.se

\begin{abstract}
A mechanism for the oxidation of a dimeric $\beta$-amyloid copper ion complex is proposed based on DFT calculations. It involves the Met35 residue, which is believed to be important in the neurotoxicity causing Alzheimer's disease. Oxidation of Met35 is found to proceed readily with dioxygen when two Met35 residues are close to each other and the copper ion. This indicates that oxidants, such as hydrogen peroxide, are not necessary for oxidation of $\beta$ amyloid copper ion complexes. Understanding these processes could be pivotal in gaining more knowledge of this complex disease and for the development of therapeutic treatments.
\end{abstract}

Keywords Alzheimer's disease $\cdot \beta$-amyloid $\cdot$ Copper ion $\cdot$ Met35 $\cdot$ Oxidation $\cdot$ Molecular modeling 


\section{Introduction}

Alzheimer's disease (AD) is an incurable degenerative brain disease. It is characterized by impaired cognitive functions that are caused by extensive neuronal loss, and the presence of numerous polypeptide aggregates forming senile plaques in the brain. These are composed of a 39-43 amino acid polypeptide called $\beta$-amyloid $(\mathrm{A} \beta)[1,2]$. While plaques are the most obvious pathological feature of $\mathrm{AD}$ it is believed that it is soluble oligomeric forms of $\mathrm{A} \beta$ rather than the deposited material that are the toxic species responsible for the neurodegeneration [3, 4]. The first row transition metals $\mathrm{Zn}, \mathrm{Cu}$, and $\mathrm{Fe}$ are highly enriched in $\beta$-amyloid deposits (plaque) in $\mathrm{AD}$ [5]. Increasing evidence has implicated oxidative stress in the pathogenesis of $\mathrm{AD}$. Since $\mathrm{Cu}$ and $\mathrm{Fe}$ are redox-active elements they may contribute to the oxidative insults that are observed in the AD-affected brain [6]. In vitro it has been shown that the $A \beta$ copper complex $(A \beta / \mathrm{Cu})$ catalyzes the formation of hydrogen peroxide $\left(\mathrm{H}_{2} \mathrm{O}_{2}\right)$ from dioxygen $\left(\mathrm{O}_{2}\right)$ and substrates, such as ascorbic acid and cholesterol [7], which has been suggested to be one route to the oxidative stress observed in AD [8]. Both Tyr10 and Met35 have been demonstrated to be of pivotal importance for the redox-chemistry of $\mathrm{A} \beta-\mathrm{Cu}[9,10]$. We propose herein a mechanism (see Fig. 1) based on Density Functional Theory (DFT) calculations showing how Met35 is oxidized to its corresponding sulfoxide when A $\beta$ forms a dimeric complex with $\mathrm{Cu}^{2+}$, using $\mathrm{O}_{2}$ as oxidant. The mechanism requires the simultaneous oxidation of two Met35 residues to their corresponding sulfoxides. A recent experimental study showed how the two Met35 residues may be brought close to each other prior oxidation by forming a $\beta$-amyloid dimer, held together by two copper ions [11]. The sulfoxide is more soluble than the corresponding thioether and the oxidation of Met35 may be a driving force for the solubilization and increased neurotoxicity of $\beta$-amyloid [12].

\section{Computational methods}

Geometry optimizations were performed with the non-local gradient-corrected B3LYP density functional and the LANL2DZ basis set using the Gaussian 03 program [13]. All optimized stationary points were checked by means of frequency calculations at the level they were geometry optimized. Unscaled frequencies were used to obtain zero-point energies. Single-point energy calculations were performed on all optimized geometries using the larger 
6-311+G** basis set. Solvation calculations were carried out with the Poisson-Boltzmann solvation model implemented in the Jaguar program [14]. The dielectric constant was set to $\varepsilon=4$ to simulate a hydrophobic environment around the reaction site of the $A \beta / \mathrm{Cu}$ complex and $\varepsilon=80$ to simulate an aqueous environment. The non-local gradient-corrected B3LYP functional and the LACVP basis set were used in these calculations. The presented energies were computed as:

$$
\mathrm{E}=\mathrm{E}_{\text {electronic }}+\mathrm{E}_{\text {Zero-point }}+\mathrm{E}_{\text {Solvation }}
$$

For two of the studied complexes (C and $\mathbf{D}$ in Fig. 2) we were not able to obtain fully optimized geometries, i.e. only the RMS force and not the Maximum force were below the default thresholds of Gaussian 03. Further optimization lead to dissociation of the molecular complexes. This is not surprising considering that both these structures have a total charge of two and consists of two positively charged monomers. The dissociation is most likely an artifact of the truncated model systems, since in the real system these complexes are likely to be held together by the protein environment.

\section{Results and discussion}

Discussed below are the results of the DFT-calculations carried out on the suggested oxidation mechanism of Met35. A detailed mechanism with its stationary points $\mathbf{A}$ through $\mathbf{F}$ referred to below is shown in Fig. 2.

\section{Met35 radical cation formation drives the reduction of $\mathrm{Cu}$ (II)}

The first step of the Met35 oxidation, as depicted in Fig. 2, involves the reduction of one of the $\mathrm{A} \beta$ bound copper ions. We assumed that one electron is transferred from one of the two Met35 residues via electron transfer to one of the copper ions, which previously has been suggested by Pogocki et al. [15]. It has been demonstrated that $\mathrm{Cu}^{2+}$ coordinates the His6, His13, and His 14, whereas the exact nature of the fourth ligand has been the subject of several conflicting studies [16]. Recent data suggest an oxygen atom ligand donated by an Asp, Gln, or the Tyr10 (in its deprotonated tyrosinate form) residue, rapidly equilibrating between

several square-planar complexes [17-18]. Here we chose Tyr10 as the fourth ligand. The reduced $\mathrm{Cu}^{+}$ion prefers a trigonal coordination comprising the His residues. Previously it was 
demonstrated how the reduction of $\mathrm{A} \beta / \mathrm{Cu}^{2+}$ involves the protonation and departure of Tyr10 from the first coordination shell around the copper ion [9]. We reasoned that for the reduction to be energetically favorable Tyr10 either does not bind to the metal or it must depart from it in an uncharged form prior to metal ion reduction. Computations were carried out to simulate such a proton exchange reaction by geometry optimization of $\mathbf{A}$ and $\mathbf{B}$ (Fig. 2). A was modeled by one $\mathrm{Cu}^{2+}$ ion coordinating three imines (modeling His6, His13 and His14), one phenolate (modeling the tyrosinate of Tyr10), and one Met35 residue was represented by the truncated amino acid $\mathrm{CH}_{3} \mathrm{NH}-(\mathrm{C}=\mathrm{O}) \mathrm{CH}_{2} \mathrm{CH}_{2} \mathrm{CH}_{2} \mathrm{SCH}_{3}$ coordinating the copper ion in an apical position. The complex was solvated by three explicit water molecules positioned around the tyrosinate side-chain oxygen. Going from $\mathbf{A}$ to $\mathbf{B}$ involves the transfer of a proton from an oxonium ion in aqueous solution to $\mathbf{A}$. The oxonium ion and the resulting water molecule were solvated in a dielectric continuum with $\varepsilon=80$. $\mathbf{A}$ and $\mathbf{B}$ were solvated by a low and high dielectric continuum using a dielectric constant value of 4 and 80 . The free energy of this proton exchange process (after taking into account the large difference in concentration when replacing the water molecule with an oxonium ion [19]) turned out to be endergonic by $13.3 \mathrm{kcal} \mathrm{mol}^{-1}$ in the low dielectric medium calculations but exergonic by $9.2 \mathrm{kcal} \mathrm{mol}^{-1}$ with a dielectric continuum modeling aqueous solution. These results suggest that the tyrosinate side-chain oxygen is protonated in water and that Tyr10 does not coordinate to the metal ion, in agreement with previous studies [16]. Selected bond lengths and spin density values of the geometry optimized structure B are presented in Fig. 3. No attempts were made to estimate the activation barrier of this electron transfer process. The reduced state of the copper complex was geometry optimized with a trigonal planar geometry around the metal ion and with the sulfur moved away from the copper center and instead coordinating one face of the aromatic ring of Tyr10. Subsequent spin-density analysis showed that one electron had escaped Met35 and had moved to the copper center reducing it to $\mathrm{Cu}^{+}$. The results indicate that the positively charged sulfur atom interacts with the negatively charged $\pi$-system of the aromatic ring. Similarly, it is known that alkali metal cations form complexes with aromatic systems [20]. The energy difference in aqueous solution going from $\mathbf{B}$ to $\mathbf{C}$ was computed to $12.4 \mathrm{kcal} \mathrm{mol}^{-1}$. In a hydrophobic environment $(\varepsilon=4.0)$ this energy difference was, however, reduced to $6.4 \mathrm{kcal} \mathrm{mol}^{-1}$. In gas phase the process is thermodynamically favored by $-6.9 \mathrm{kcal}$ $\mathrm{mol}^{-1}$. Unfortunately, it is difficult to estimate the local dielectric constant around the copper ion since no structural data exist. However, the results agree with experimental data, which show that methionine is a poor reducing agent for copper in solution [21-22]. The positively charged sulfur has been suggested to be stabilized by its backbone carbonyl oxygen [23]. As 
can be seen in Fig. 4 the carbonyl oxygen - sulfur distance has decreased from $3.65 \AA$ in $\mathbf{B}$ to $2.85 \AA$ in $\mathbf{C}$.

Pogocki et al. argued that Met35 is not in close proximity to $\mathrm{Cu}^{2+}$ during the electron transfer due to the distance in amino acid residue sequence and the presumed $\alpha$-helical secondary structure in which environment the reduction is taking place. However, if such a process occurs with the Met35 far from the copper ion the sulfoxide would not form since Rauk et al. [24] and Albini et al. [25] have demonstrated that dioxygen does not bind covalently to the radical cation. Instead, the acidity of the formed Met35 radical cation would make it deprotonate. The formed neutral radical would then add $\mathrm{O}_{2}$ to a carbon neighboring the sulfur producing a carbon-centered peroxy radical. Egnaczyk et al. demonstrated that Met35, which is located near the C-terminal, can be in close proximity to Phe4 located near the N-terminal (thus probably close to His6, Tyr10, His13, and His14) by using a photo-affinity cross-linking technique to insert $L$-p-benzoylphenylalanine (replacing Phe4) into the $\delta$-methyl group of Met35 [26]. In addition, Murakami et al. demonstrated, using electron spin resonance, that Met35 and Tyr10 are close in space [27-28]. Hence, we argue that Met35 must come close to $\mathrm{Cu}^{2+}$ during the electron transfer process, taking active part in the redox chemistry with the metal ion.

\section{The production of sulfoxide involves formation of a persulfoxide intermediate}

Foote et al. suggested a mechanism how sulfoxides form from thioethers in sensitized photooxidations [29]. Here singlet dioxygen reacts with the thioether producing a persulfoxide intermediate, being an $\mathrm{R}_{2}-\mathrm{S}^{+}-\mathrm{OO}^{-}$zwitter ion, or possibly the biradical $\mathrm{R}_{2}-\mathrm{S}^{*}-$ $\mathrm{OO}^{*}$ or the cyclic thiadioxirane of $\mathrm{R}_{2}-\mathrm{SOO}$. This high-energy intermediate then reacts with another thioether forming two sulfoxides $\left(\mathrm{R}_{2}-\mathrm{S}=\mathrm{O}\right)$. The reaction is very slow in diethyl ether, benzene and dry acetonitrile, however, it is accelerated when adding small amounts of water to the solution. Correa et al. reported that the same reaction gives a high yield without sensitizers, but with a 40 atm $\mathrm{O}_{2}$-pressure in polar solvents and elevated temperatures [30]. The same group reported catalytic conversion of dialkylsulfides to their corresponding sulfoxides when mixed with $\mathrm{O}_{2}$ and $\mathrm{Ce}(\mathrm{IV}) / \mathrm{Ce}(\mathrm{III})$ ammonium nitrate salts. No catalysis could be achieved with salts formed from metal ions such as $\mathrm{Fe}^{3+}, \mathrm{Ru}^{3+}, \mathrm{Ag}^{+}$, and $\mathrm{Mo}^{5+}$. The fact that Met35 is a weak, but still sufficient reducing agent, that converts $\mathrm{Cu}$ (II) to $\mathrm{Cu}(\mathrm{I})$ has been attributed to its ability to stabilize the formed sulfur radical cation via the lone-pairs of the backbone carbonyl oxygen (see Fig. 4). Thus, the oxidation of Met35 likely proceeds 
through the stationary points $\mathbf{A}, \mathbf{B}$, and $\mathbf{C}$. Therefore, it seems feasible that dioxygen adds to the reduced copper center and forms a superoxide radical anion which then rapidly reacts with the Met35 radical cation. The change in free energy upon coordination of $\mathrm{O}_{2}$ to $\mathrm{Cu}^{+}$should not be very unfavorable since an X-ray structure has been reported where $\mathrm{O}_{2}$ binds to a $\mathrm{Cu}$ center coordinating His and Met residues [31]. By taking this is into account the formation of D (see Fig. 4) from $\mathbf{C}$ and free dioxygen should be energetically accessible. Baciowcchi et al. demonstrated by using the ab initio method G3 that the dimethyl persulfoxide zwitter ion and the corresponding thiadioxirane are almost isoenergetic [32]. Hence, dioxygen adds to $\mathrm{Cu}^{+}$ (D), gets reduced, and reacts with the radical cation of the Met35 model forming a zwitter ion. Then, it reacts with a second Met35 residue (modeled by dimethylsulfide) forming $\mathbf{E}$. This process turned out to be thermodynamically favored in both the low and high dielectric medium by $-9.2 \mathrm{kcal} \mathrm{mol}^{-1}$ and $-12.2 \mathrm{kcal} \mathrm{mol}^{-1}$ respectively. A transition state $\mathbf{F}$ (see Fig 5.) and product complex $\mathbf{G}$ were located and geometry optimized. The results of these calculations show that the reaction is highly exothermic $\left(-54.4 \mathrm{kcal} \mathrm{mol}^{-1}, \mathbf{F}\right.$ to $\mathbf{G}$ in water solution) and the computed activation energy barrier is $15.2 \mathrm{kcal} \mathrm{mol}^{-1}$ ( $\mathbf{E}$ to $\mathbf{F}$ ) in aqueous solution. Thus, the oxidation of Met35 requires two methionine residues in close proximity, which is supported by the dimeric $A \beta$ recently observed [11]

\section{Oxidation of $\beta$-amyloid peptide in the presence of $\mathrm{H}_{2} \mathrm{O}_{2}$}

Chu and Trout recently suggested a mechanism, based on ab initio calculations, of the dimethylsulfide oxidation to dimethyl sulfoxide. The reaction was modeled in water solution and $\mathrm{H}_{2} \mathrm{O}_{2}$ was used as oxidant [33]. They computed an activation barrier of $12.7 \mathrm{kcal} \mathrm{mol}^{-1}$ (using MP4//B3LYP/6-31++G(d,p) level of theory), which is in agreement with experiments. This suggests that oxidation of Met35 in an environment rich on $\mathrm{H}_{2} \mathrm{O}_{2}$ should be rapid. Hence, in an environment rich on dioxygen and reducing substrates, $\mathrm{A} \beta-\mathrm{Cu}^{2+}$ may first catalyze the formation of $\mathrm{H}_{2} \mathrm{O}_{2}$, which then quickly oxidizes Met35. However, in an environment where efficient enzymatic degradation of $\mathrm{H}_{2} \mathrm{O}_{2}$ occurs the suggested mechanism shows how Met35 can be oxidized by molecular oxygen when present in a dimeric $\mathrm{A} \beta-\mathrm{Cu}^{2+}$ complex. 


\section{Summary}

On the basis of density functional theory calculations we suggest a molecular mechanism for the oxidation of Met35 in a $\beta$-amyloid copper complex by molecular oxygen. The mechanism requires that $\beta$-amyloid forms a dimeric complex with $\mathrm{Cu}^{2+}$. The two neighboring Met35 residues are simultaneously oxidized by oxygen to their corresponding sulfoxides, which results in increased water solubility. These findings may be important for understanding the neurotoxicity of solubilized $\beta$-amyloid and its involvement in the Alzheimer's disease. 


\section{References}

1. Mattson MP (2004) Nature 430:631-639

2. Hardy J, Selkoe DJ (2002) Science 297:353-356

3. McLean CA, Cherny RA, Fraser FW, Fuller SJ, Smith MJ, Beyreuther K, Bush AI, Masters CL (1999) Ann Neurol 46:860-866

4. Walsh DM, Klyubin I, Fadeeva JV, Cullen WK, Anwyl R, Wolfe MS, Rowan MJ, Selkoe DJ (2002) 416:535-539

5. Lovell MA, Robertson JD, Teesdale WJ, Campbell JL, Markesbery WR (1998) Neurol Sci 158:47-52

6. Huang X, Atwood CS, Hartshorn MA, Multhaup G, Goldstein LE, Scarpa RC, Cuajungco MP, Gray DN, Lim J, Moir RD, Tanzi RE (1999) Biochemistry 38:7609-7616

7. Cutler G, Kelly J, Storie K, Pedersen WA, Tammara A, Hatanpaa K, Troncoso JC, Mattson MP (2004) Proc Natl Acad Sci 101: 2070-2075

8. Curtain CC, Ali F, Volitakis I, Cherny RA, Norton RS, Beyreuther K, Barrow CJ, Masters CL, Bush AI, Barnham KJ (2001) J Biol Chem 276:20466-20473

9. Barnham KJ, Haeffner F, Ciccotosto GD, Curtain CC, Tew D, Mayros C, Beyreuther K, Carrington D, Masters CL, Cherny RA, Cappai RR, Bush AI (2004) FASEB J 18:14271429

10. Butterfield DA, Boyd-Kimball D (2005) Biochim Biophys Acta Proteins \& Proteomics 1703:149-156

11. Tickler AK, Smith DG, Ciccotosto GD, Tew DJ, Curtain CC, Carrington D, Masters CL, Bush AI, Cherny RA, Cappai R, Wade JD, Barnham KJ (2005) 280-13355-13363

12. Ciccotosto GD, Barnham KJ, Cherny RA, Masters CL, Bush AI, Curtain CC, Cappai R, Tew D (2003) Lett Pep Sci 10:413- 417

13. Frisch MJ, Trucks GW, Schlegel HB, Scuseria GE, Robb MA, Cheeseman JR, Montgomery JA, Vreven T Jr, Kudin KN, Burant JC, Millam JM, Iyengar SS, Tomasi J, Barone V, Mennucci B, Cossi M, Scalmani G, Rega N, Petersson GA, Nakatsuji H, Hada M, Ehara M, Toyota K, Fukuda R, Hasegawa J, Ishida M, Nakajima T, Honda Y, Kitao O, Nakai H, Klene M, Li X, Knox JE, Hratchian HP, Cross JB, Bakken V, Adamo C, Jaramillo J, Gomperts R, Stratmann RE, Yazyev O, Austin AJ, Cammi R, Pomelli C, Ochterski JW, Ayala PY, Morokuma K, Voth GA, Salvador P, Dannenberg JJ, Zakrzewski VG, Dapprich S, Daniels AD, Strain MC, Farkas O, Malick DK, Rabuck AD, Raghavachari K, Foresman JB, Ortiz JV, Cui Q, Baboul AG, Clifford S, Cioslowski J, 
Stefanov BB,, Liu G, Liashenko A, Piskorz P, Komaromi I, Martin RL, Fox DJ, Keith T, Al-Laham MA, Peng CY, Nanayakkara M, Challacombe M, Gill PMW, Johnson B, Chen W, Wong MW, Gonzalez C, Pople JA (2004) Gaussian 03, Revision E.01. Gaussian Inc, Wallingford CT

14. Jaguar version 6.0 Schrodinger, LLC, Portland, OR, (2005)

15. Pogocki D (2004) Chem Res Toxicol 17:325-329

16. Guilloreau L, Damian L, Coppel Y, Mazarguil H, Winterhalter M, Faller P (2006) J Biol Inorg Chem 11:1024-1038

17. Streltosov VA, Titmuss SJ, Epa VC, Barnham KJ, Masters CL, Varghese JN (2008) Biophys J 95-3447-3456

18. Drew SC, Noble CJ, Masters CL, Hanson GR, Barnham KJ (2009) J Am Chem Soc 131:11951207

19. A correction of $11.9 \mathrm{kcal} \mathrm{mol}^{-1}$ has been included for changing the standard state from 1 $\mathrm{M}$ in all species to $10^{-7} \mathrm{M}$ in $\mathrm{H}_{3} \mathrm{O}^{+}$and $55 \mathrm{M}$ in $\mathrm{H}_{2} \mathrm{O}$

20. Dougherty DA (1996) Science 271:163-168

21. Huang X, Cuajungco MP, Atwood CS, Hartshorn MA, Tyndall JD, Hanson GR, Stokes KC, Leopold M, Multhaup G, Goldstein LE, Scarpa RC, Saunders AJ, Lim J, Moir RD, Glabe C, Bowden EF, Masters CL, Fairlie DP, Tanzi RE, Bush AI (1999) J Biol Chem 274:37111-37116

22. Sanaullah, Wilson GS, Glass RS (1994) J Inorg Biochem 55:87-93

23. Pogocki D, Serdiuk K, Schöneich C (2003) J Phys Chem A 107-7032-7042

24. Huang LM, Rauk A (2004) J Phys Chem A 108:6222-6230

25. Bonesi SM, Manet I, Freccero M, Fagnoni M, Albini A (2006) Chemistry - A european journal 12:4844-4857

26. Egnaczyk GF, Greis KD, Stimson ER, Maggio JE (2001) Biochemistry 40:11706-11714

27. Murakami K, Irie K, Ohigashi H, Hara H, Nagao M, Shimizu T, Shirasawa T (2005) J Am Chem Soc 127:15168-15174

28. Murakami K, Hara H, Masuda Y, Ohigashi H, Irie K (2007) Chembiochem 8:2308-2314

29. Foote CS, Peters JW (1971) J Am Chem Soc 93:3795-3796

30. Correa PE, Riley DP (1985) J Org Chem 50:1787-1788

31. Prigge ST, Eipper BA, Mains RE, Amzel LM (2004) Science 304:864-867

32. Baciocchi E, Del Giacco T, Elisei F, Gerini MF, Guerra M, Lapi, A, Liberali P (2003) J Am Chem Soc 125:16444-16454

33. Chu J-W, Trout BL (2004) J Am Chem Soc 126:900-908 


\section{Figure captions}

Fig. 1 Suggested mechanism of how both Met35 residues in the $(A \beta-C u)(A \beta-C u)$ dimer are oxidized by one $\mathrm{O}_{2}$ molecule

Fig. 2 Suggested mechanism of the oxidation of Met 35 in the $A \beta / C u$ dimeric complex

Fig. 3 Geometry optimized structure (B) in which one $\mathrm{H}_{3} \mathrm{O}^{+}$hydrogen bonds to the tyrosinate of Tyr10 and two $\mathrm{H}_{2} \mathrm{O}$ molecules. The sulfur atom of Met35 coordinates to $\mathrm{Cu}^{2+}$. Selected bond lengths are presented in italics and electron spin densities are presented in bold

Fig. 4 Geometry optimized structure $(\mathbf{C})$. The positive charge on the sulfur of the Met35 radical cation is stabilized by its backbone carbonyl oxygen as well as by a $\pi$ interaction with the side-chain of Tyr10. The copper center is reduced to $\mathrm{Cu}^{+}$ coordinating three His residues in a trigonal arrangement. Selected bond lengths are presented in italics and electron spin densities are presented in bold

Fig. 5 Geometry optimized transition state $(\mathbf{F})$ in which the two MetO sulfoxides form from one persulfoxide (Met35-SOO) intermediate and one Met35 residue. Selected bond lengths are presented in italics and electron spin densities are presented in bold 


\section{$\beta$-amyloid copper ion dimeric complex}

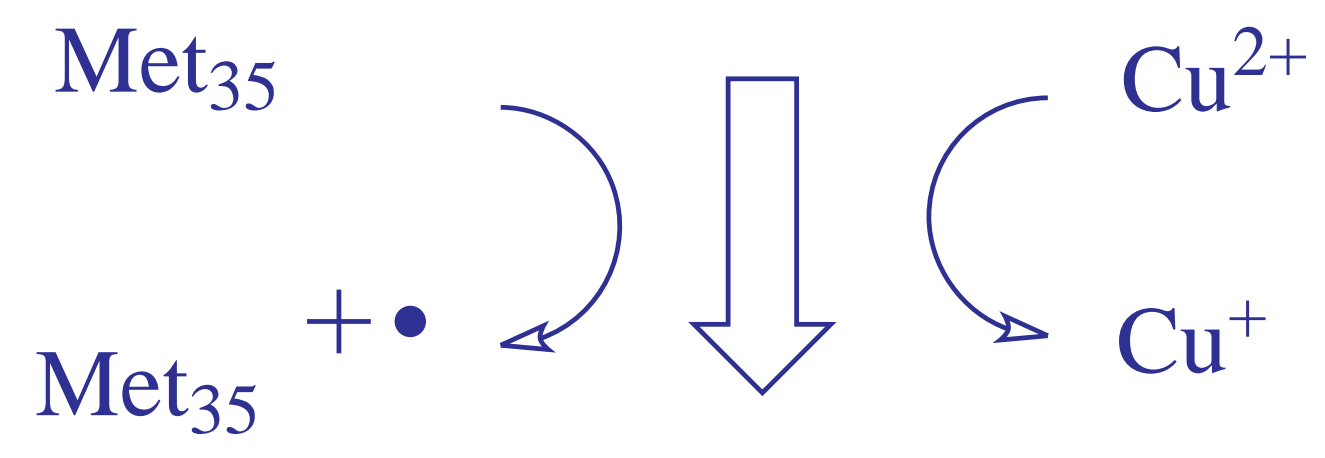

$\left(\mathrm{A} \beta\left(\mathrm{Met}_{35}{ }^{{ }^{*}}\right) / \mathrm{Cu}^{+}\right)\left(\mathrm{A} \beta\left(\mathrm{Met}_{35}\right) / \mathrm{Cu}^{2+}\right)$

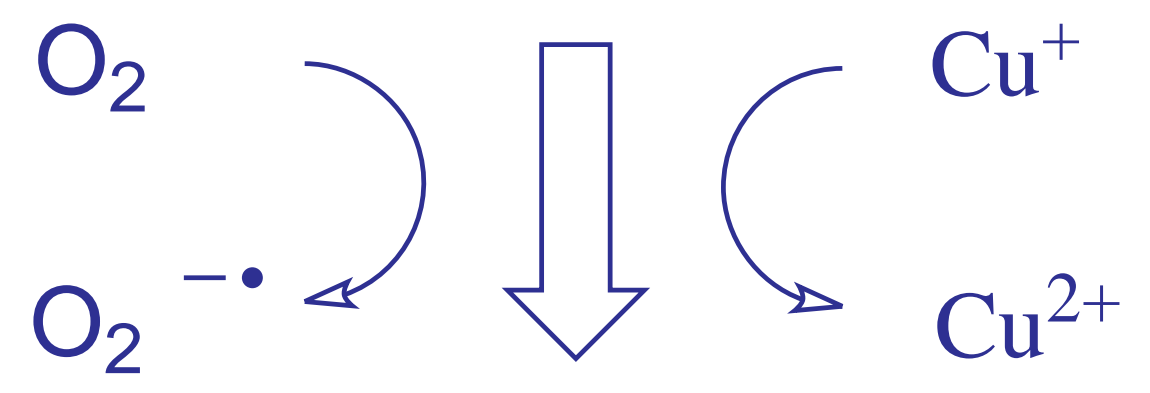

$\left(\mathrm{A} \beta\left(\mathrm{Met}_{35} \mathrm{O}\right) / \mathrm{Cu}^{2+}\right)\left(\mathrm{A} \beta\left(\mathrm{Met}_{35} \mathrm{O}\right) / \mathrm{Cu}^{2+}\right)$ 


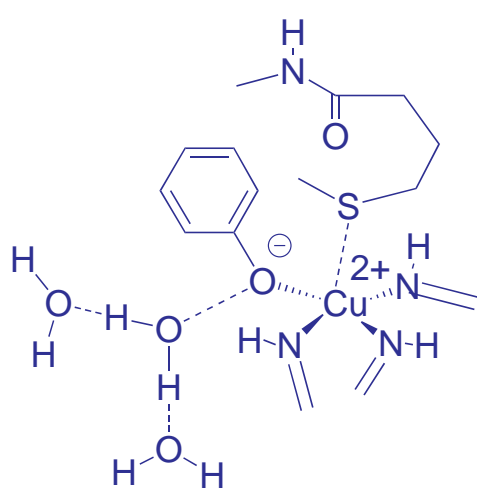

A<smiles>[Z7]C(N=C)(N=C)[N+](=C)NC</smiles>

F<smiles>C=N[C+]1(O[SH](C)OCO)OC(NC)CCS1</smiles>

G
B

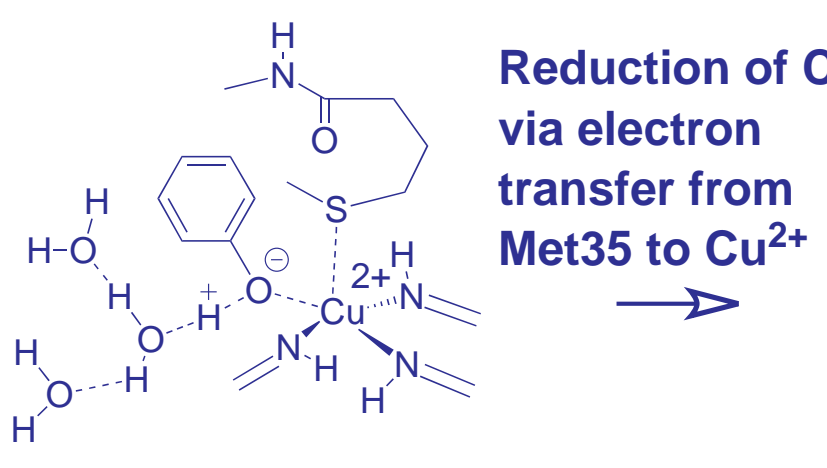

\section{E}

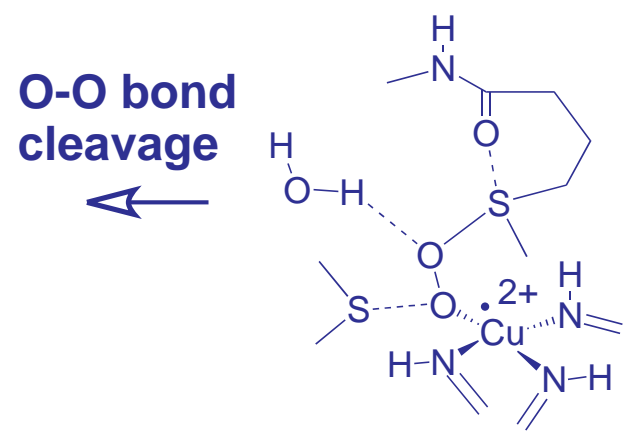

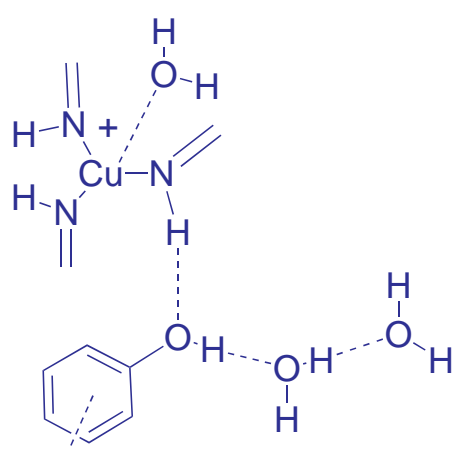

C<smiles>CNC(=O)CCC[Sn](C)(C)C</smiles><smiles>CSC</smiles>

$\mathrm{O}_{2}$

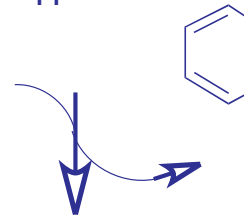<smiles>CNC</smiles>

D<smiles>C1CCCCC1</smiles>
$\mathrm{O}_{1}^{-}-\mathrm{H}^{\prime}$<smiles>C=NN(OOO)[Ge](N=C)(N=C)N=C</smiles>

Fig 2 


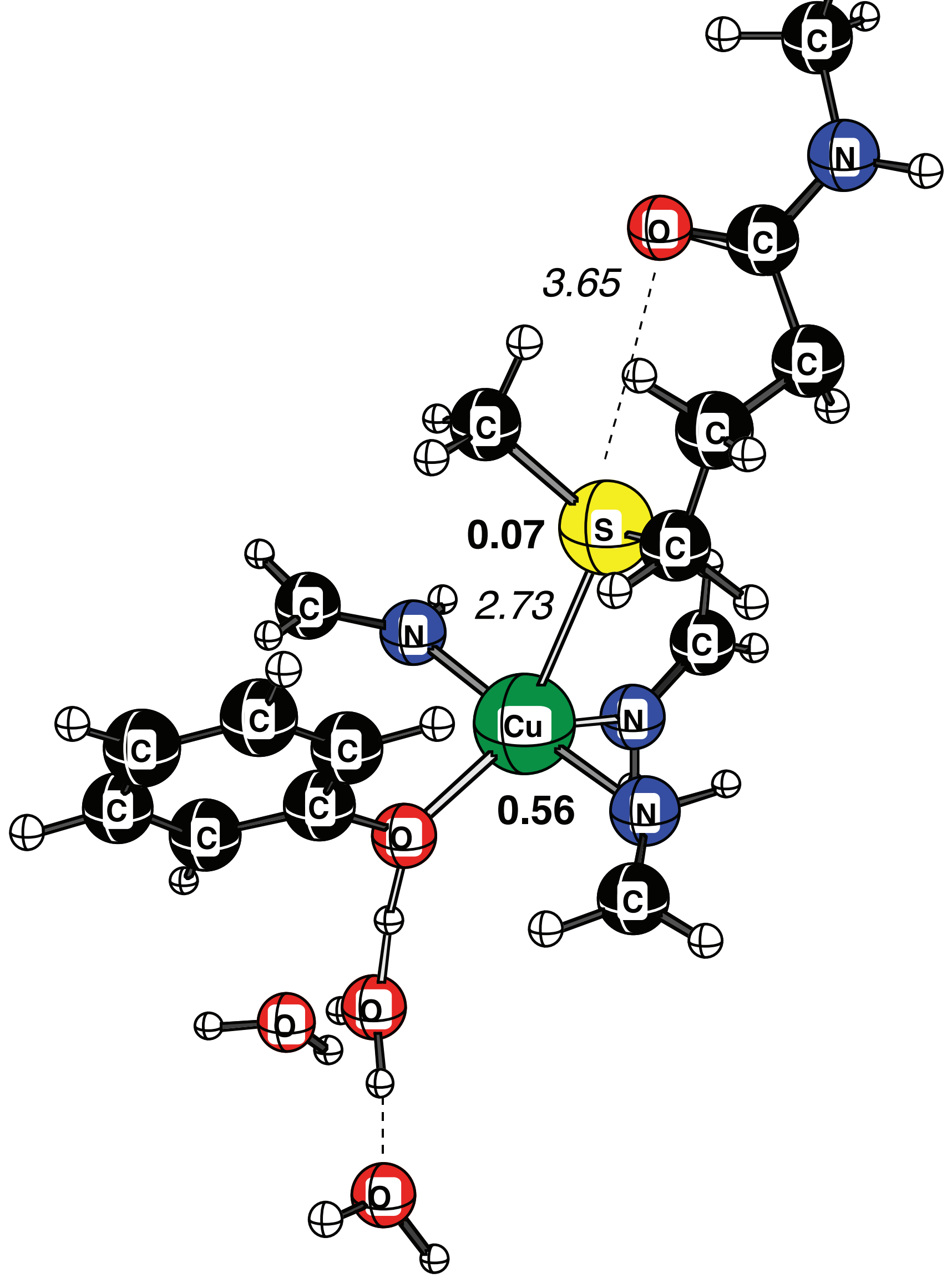

Fig 3 


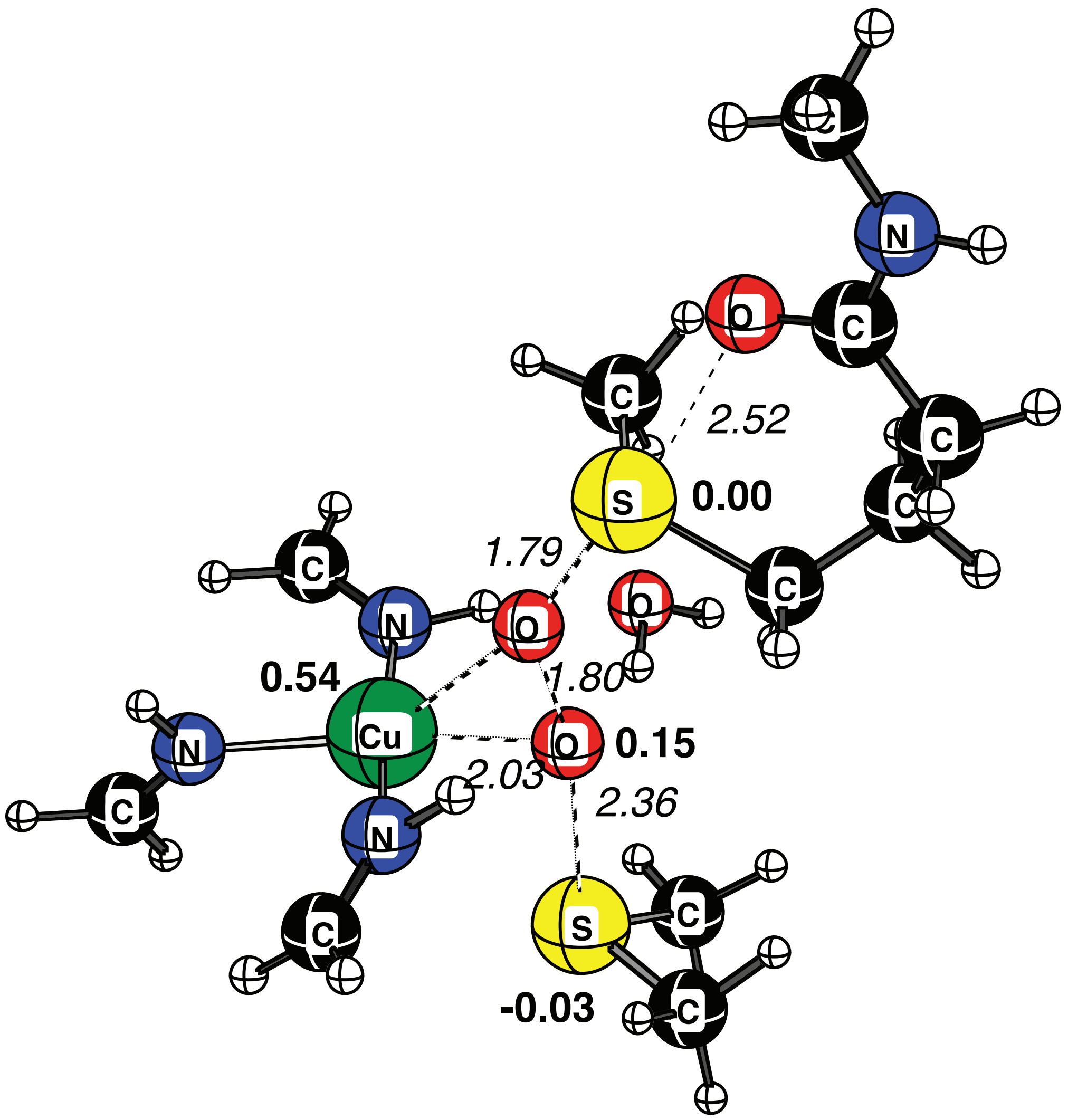

Fig 5 